\title{
Production of Gypsum from Clamshells and Waste Acid Recovered from End-of-Life Lead Acid Batteries*
}

\author{
${ }^{1}$ H. D. Gohoho and ${ }^{2}$ J. R. Dankwah \\ ${ }^{1}$ Ghana Standards Authority, Accra, Ghana \\ ${ }^{2}$ University of Mines and Technology, Post Office Box 237, Tarkwa, Ghana
}

Gohoho, H. D. and Dankwah, J. R. (2019), "Production of Gypsum from Clamshells and Waste Acid Recovered from End-of-Life Lead Acid Batteries", Ghana Mining Journal, Vol. 19, No. 1, pp. 66 - 71.

\begin{abstract}
Gypsum exists in the Dihydrate $\left(\mathrm{CaSO}_{4} 2 \mathrm{H}_{2} \mathrm{O}\right)$, Hemihydrate $\left(\mathrm{CaSO}_{4} \cdot{ }^{1 / 2} \mathrm{H}_{2} \mathrm{O}\right)$ and the Anhydrite $\left(\mathrm{CaSO}_{4}\right)$ forms. The exploitation of the natural rock form deposit of gypsum is on the increase, necessitating the need to find alternative and efficient sources of gypsum so as to sustain all the industries dependent on gypsum as raw material. This work investigates the production of gypsum from clamshells and waste sulphuric acid from end-of-life car batteries. Clamshells obtained from the Volta Region of Ghana were calcined at a temperature of about $1000{ }^{\circ} \mathrm{C}$ with a view of producing $\mathrm{CaO}$ which was pulverised to particle size of $96 \%$ passing $106 \mu \mathrm{m}$. Samples of the Pulverised Clam Shells (PCS) were then reacted with five different concentrations of the Waste Battery Acid (WBA). The reaction was observed to be very exothermic; a temperature of $101{ }^{\circ} \mathrm{C}$ was obtained for the $6.5 \mathrm{M}$ concentration of WBA. The resulting mixture was filtered and an XRD analysis was performed on the oven dried residue to ascertain its composition. The findings from the work revealed that $100 \mathrm{~g}$ of pulverised clam shells produced an average of $58.08 \mathrm{~g}$ of calcined product and $134 \mathrm{~g}$ of gypsum. Peaks of $\mathrm{SiO}_{2} \mathrm{and}_{\mathrm{CaCO}}$ in the XRD diffractogram of the gypsum indicated that the reaction between PCS and WBA was incomplete. Conclusively, the results from the XRD analysis showed peaks of the three forms of gypsum that was successfully produced.
\end{abstract}

Keywords: Net Present Value, Internal Rate of Return, Sensitivity Analysis, Risk Analysis

\section{Introduction}

Clam is the general common name of any molluscs within the class Bivalvia. Clams are bivalves having two shells of equal size connected by two adductor muscles and having burrowing foot. The sale of clams is a lucrative business for the indigenes living along the Volta River or lake in Ghana. It is known as "Adordi" by the local people. Clam shells are not consumed in Ghana so once the food is taken out; the shells are stockpiled for sale. The shells can be stockpiled for months awaiting buyers due to lack of readily available processing technology.

The locals in the community use the shells in poultry feeds as a source of calcium and also as feedstock in white wash paint, soil conditioning, erosion checks and concrete works. Huge tonnes of shells lie ideal in the community when not purchased. The shell heaps have visual impacts, have foul stenches and serve as breeding grounds for mosquitoes and some wild reptiles like snakes, etc.

Clam shells and other sea-related shells contain predominantly calcium carbonate $\left(\mathrm{CaCO}_{3}\right)$ and some silica $\left(\mathrm{SiO}_{2}\right)$ used in the production of lime (CaO) (Nordin et al., 2015), which can be further transformed into gypsum (calcium sulphate Dihydrate $\mathrm{CaSO}_{4} .2 \mathrm{H}_{2} \mathrm{O}$ ). (Ni'mah et al., 2018). Gypsum is the first mineral to crystallize when sea water evaporates. (Warren, 2006). It is a very soft mineral and is second on the Mohr's scale of hardness. (Thorman, 1973) Gypsum can be produced by drying, grinding and calcination of the natural rock to produce natural gypsum or by the synthetic way which can be done in several ways to produce synthetic gypsum. Flue Gas Desulphurization (FGD) with lime or limestone is one of the means of producing synthetic gypsum. Gypsum plays an important role in the cement industry as the main retarding and setting agent, plasterboards industry for decors and the agriculture industry as a soil conditioner and a source of minerals for some plants like peanuts.

Waste acids can be recovered from end-of-life car batteries in the form of highly concentrated sulphuric acid. After the useful life of the batteries, the acid and other components are improperly disposed into the environment. Countries with strict environmental regulations are against the improper disposal of these waste car batteries into their land fill sites. In Ghana, the acids are just discarded into the environment; these acids are highly concentrated and contain traces of lead metal. Lead is a heavy metal which, if not properly disposed, can leach into underground water and the ecological cycle (food chain). Artisanal and Small Scale Gold Miners use the acid to further clean their gold after smelting. Large volumes of these acids are generated by the automobiles and Uninterrupted Power Supplies; hence there is the need to find an environmentally sustainable way of disposing and recycling the acid. 
Buasri et al. (2013) observed that the calcination of various forms of sea shells (mussel, cockle and scallop) at temperatures around $1000{ }^{\circ} \mathrm{C}$ leads to the formation of calcium oxide (up to about 99.170 wt\% CaO). Ni'mah et al., (2018) investigated the production of gypsum from blends of calcined samples of clamshell and eggshell. They concluded that optimum amounts of gypsum could be produced from a blend consisting of $20 \mathrm{wt} \%$ eggshell, $20 \mathrm{wt} \%$ clamshell, $20 \mathrm{wt} \% \mathrm{H}_{2} \mathrm{SO}_{4}$ and 40 wt $\% \mathrm{H}_{2} \mathrm{O}$. Ni'mah et al., (2016) had earlier investigated the production of gypsum board from calcined eggshell waste, concluding that $35 \%$ calcined material, $50 \%$ aquadest and $15 \%$ sulfuric acid, with an elapsed time of 5.5 mins producing the best results. In all the investigations mentioned above, the $\mathrm{H}_{2} \mathrm{SO}_{4}$ used was not a waste material; it was purchased fresh by the authors.

The specific objectives of this research are therefore to reduce the environmental impacts of clamshells heaps and waste battery acid in the community and also to produce gypsum from pulverised clamshells (PCS) using waste concentrated sulphuric acid $\left(\mathrm{H}_{2} \mathrm{SO}_{4}\right)$ from car battery.

\section{Resources and Methods Used}

\subsection{Preparation of Clam Shells}

Samples of the clamshells (Fig. 1) were collected from Sogakope in the Volta Region of Ghana. These were washed thoroughly with clean water to remove the dirt and mud attached to some of the shells. The thoroughly washed shells were then sun dried for seven (7) days to remove any physically bound water.

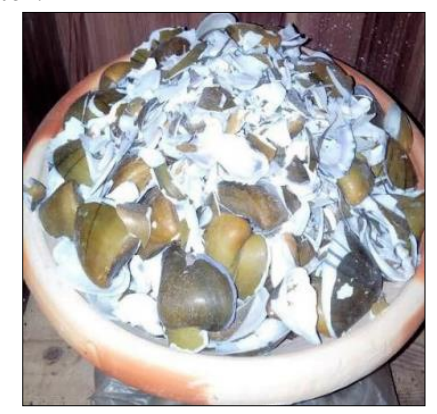

Fig. 1 Samples of Clamshells before Calcination

\subsection{Calcination of the Clam Shells}

A representative sample was taken for calcination at temperatures of $1000{ }^{\circ} \mathrm{C}$. The material was calcined at $1000{ }^{\circ} \mathrm{C}$ for 2 hours to drive off all volatiles as well as expel $\mathrm{CO}_{2}$ associated with the clam shell samples. Samples of the calcined clamshells are shown in Fig. 2.
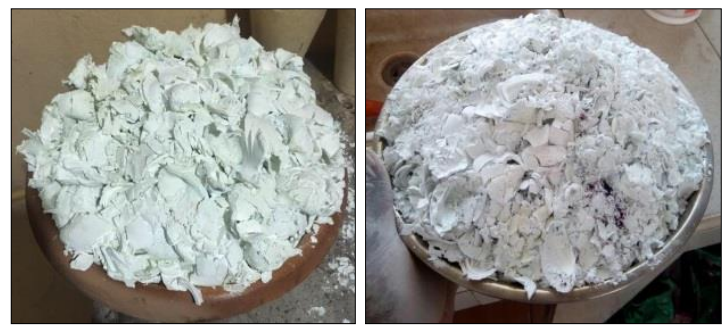

Fig. 2 Samples of Calcined Clam Shells

\subsubsection{Weight loss associated with Calcination Process}

As the calcination process drives off chemically bound water, volatiles, organic components and also some gases, the weight loss that occurred during the calcination process was determined.

\subsubsection{Pulverisation of the Calcined Clam Shells}

The calcined clam shells were allowed to cool down and were subsequently pulverised in a ball mill for 30 minutes using a steel ball loading of mass $14 \mathrm{~kg}$. Samples of the pulverised clamshells are shown in Fig. 3.

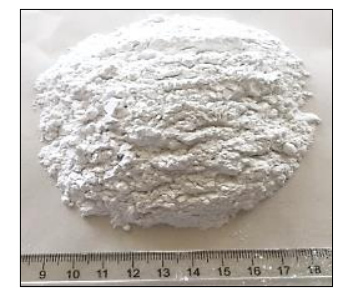

Fig. 3 Pulverized Clam Shells

\subsection{Solubility Analysis and $\mathrm{pH}$ of the $\mathrm{CaO}$ Produced}

About $100 \mathrm{~g}$ of the pulverised clamshells were dissolved in $1000 \mathrm{ml}$ of water to determine the solubility of the calcium oxide $(\mathrm{CaO})$ produced. The resulting solution was poured into a 5 litre bottle and set for bottle roll for 24 hours.

After 24 hours, the solution was filtered and the residue was dried in an oven to remove all moisture; the change in the mass of the $100 \mathrm{~g}$ sample used for the test establishes the solubility of the pulverised clam shells to be around $5 \mathrm{~g} / \mathrm{L}$

The $\mathrm{pH}$ of the filtrate together with the solids was measured; a $\mathrm{pH}$ of 12.1 was recorded.

\subsection{Particle Size Analysis of the $\mathrm{CaO}$}

Particle size analysis was conducted on the $\mathrm{CaO}$ obtained after the calcination of the clam shells. About $100 \mathrm{~g}$ of the pulverised clam shell was used and $3.7 \mathrm{~g}$ was retained on the $106 \mu \mathrm{m}$ screen getting a particle size of $96 \%$ passing $106 \mu \mathrm{m}$. 
A $63 \mu \mathrm{m}$ screen was also used and $17.1 \mathrm{~g}$ was retained, obtaining a particle size of $82.9 \%$ passing $63 \mu \mathrm{m}$.

\subsection{Preparation of Sample Solutions of Waste-acid from Car Batteries}

The waste-acid from batteries was obtained from Auto-Electricians that replace the electrolyte (i.e. sulphuric acid) in car batteries in the Tarkwa Nsuaem Community. More than 3-5 litres of waste-acid is generated and discarded on daily basis by each technician in the community. Five (5) litres of waste acid (Fig. 4) was obtained and the specific gravity checked using a hydrometer.

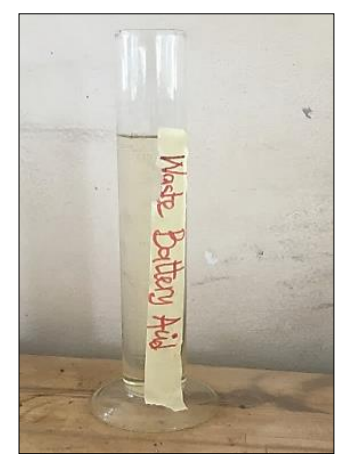

Fig. 4 Waste Battery Acid obtained in the Raw Form

Specific gravity of $1.25 \mathrm{~g} / \mathrm{cm}^{3}$ was recorded indicating a very high concentration of the acid. $250 \mathrm{ml}$ of the $18.75 \mathrm{M}$ Sulphuric acid was diluted to $4.5 \mathrm{M}, 5 \mathrm{M}, 5.5 \mathrm{M}, 6 \mathrm{M}, 6.5 \mathrm{M}$ concentrations (Fig. 5) for the reaction of the pulverised clam shells into calcium sulphate.

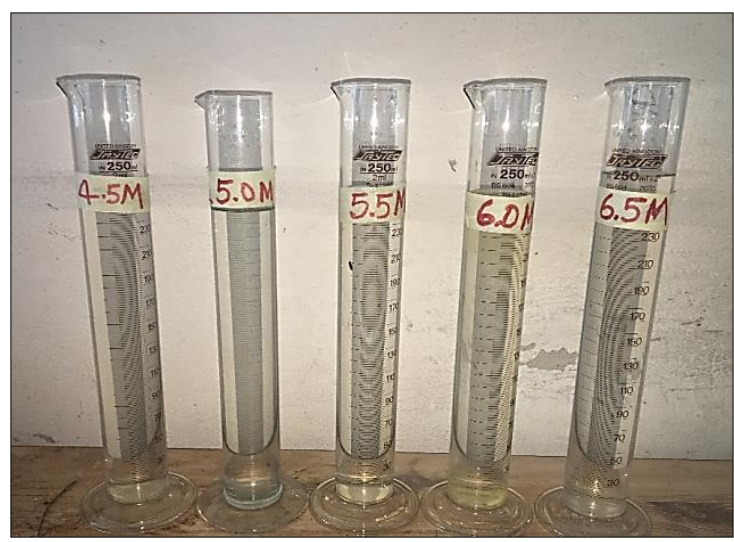

Fig. 5 Samples of Five Concentrations of WBA used for the Experiment

Atomic absorption spectrophotometric analysis (AAS) was done on the waste battery acid obtained to check the lead content in order to ascertain its harmfulness to the environment when wrongfully disposed. A substantial amount of $1.0503 \mathrm{mg} / \mathrm{L}$ of lead $(\mathrm{Pb})$ was recorded in the $4.5 \mathrm{M}$ concentration of the WBA; the stock WBA contains $4.167 \mathrm{mg} / \mathrm{L}$ of lead $(\mathrm{Pb})$.

\subsection{Reaction of the Pulverised Clam Shells with Sulphuric acid}

About $100 \mathrm{~g}$ of the pulverised clam shells were reacted with the various concentrations of sulphuric acid prepared. The reaction is exothermic and thus was monitored with a Digital 2 k-type Thermocouple Thermometer (Nicety DT804A) to determine the time taken for the reaction to be completed and also the maximum temperature at which the reaction was completed. The solution was then filtered and the $\mathrm{pH}$ of the filtrate was recorded.

\subsection{Drying and Analysis of the Residue}

The residue after the reaction was oven dried for 48 hours at temperatures around $130{ }^{\circ} \mathrm{C}$ and the dried residue (Fig. 6) was weighed. A representative sample of the dried residue was taken for XRD analysis.
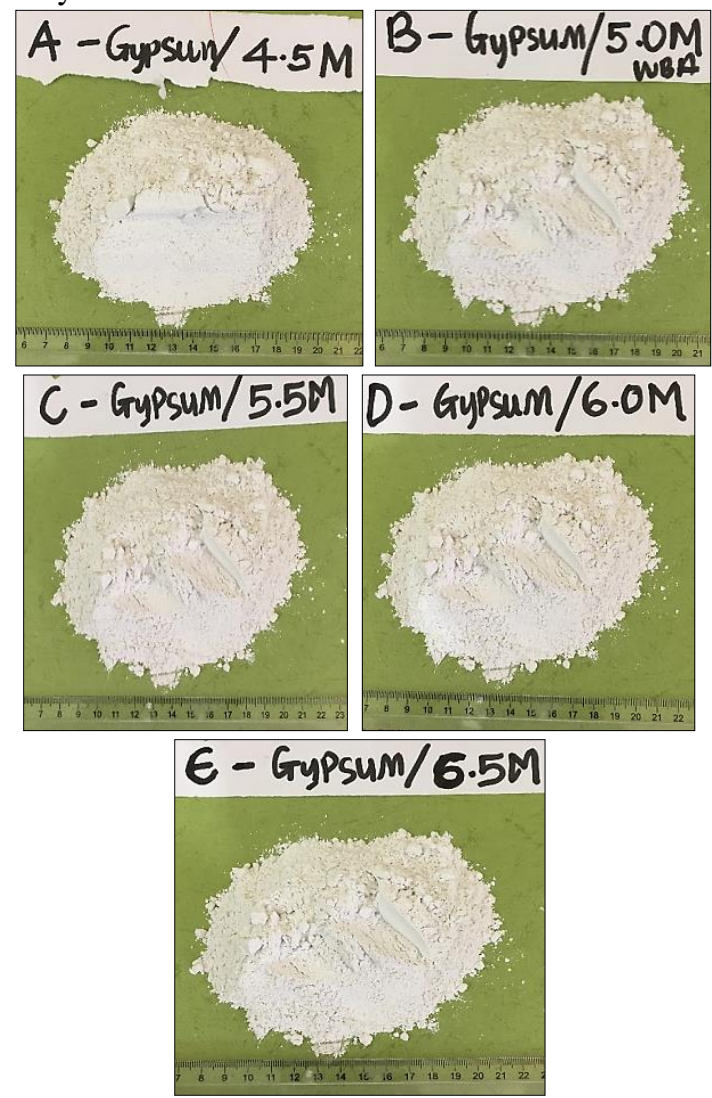

Fig. 6 Dried Residue of the Respective Concentrations WBA used 


\section{Results and Discussion}

\subsection{Calcination of Clamshells}

The calcination of $\mathrm{CaCO}_{3}$ and the Gibbs free energy change that accompanies the calcination process are illustrated below (Gilchrist, 1989):

$$
\begin{aligned}
& \mathrm{CaCO}_{3(s)} \rightarrow \mathrm{CaO}_{(s)}+\mathrm{CO}_{2(\mathrm{~g})} \\
& \Delta G_{r}^{o}=177,100-158 \mathrm{~T} \quad(\mathrm{~J} / \mathrm{mol})
\end{aligned}
$$

From equation (2), the equilibrium temperature for the calcination of pure $\mathrm{CaCO}_{3}$ is about $848{ }^{\circ} \mathrm{C}$, suggesting that temperatures in excess of about 900 ${ }^{\circ} \mathrm{C}$ should be sufficient for the process. Complete calcination of pure $\mathrm{CaCO}_{3}$ is accompanied by a weight loss of about $43.97 \%$ that stoichiometrically corresponds to complete expulsion of $\mathrm{CO}_{2}$ gas.

Since the clamshells were given sufficient time to dry, the percent calcination was calculated based on the maximum weight loss attributed to $\mathrm{CO}_{2}$ and was expressed by equation (3) as follows:

$$
\% \text { Calcination }=\frac{\% \text { weight loss }}{43.97} \times 100
$$

Fig. 7 shows the percent calcination and the percentage weight loss associated with the calcination of the clam shells. It is clear that the weight loss ranged from about $41.32 \%$ to about $43.20 \%$ with an average of $41.92 \%$. This gives an average percent calcination of about $95.33 \%$, with a range of $93.97-98.25 \%$, suggesting that calcination is incomplete. However, eqn. (3) is based on $100 \% \mathrm{CaCO}_{3}$ purity, which cannot be said to be the case of the clam shells used for the investigation. This is explained further under Section 3.5.

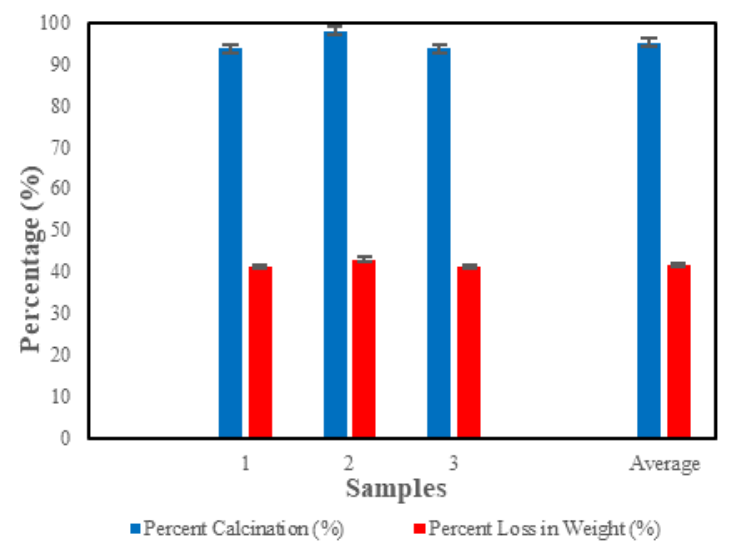

Fig. 7 Graph of Percent Weight Loss after Calcination

\subsection{Volume of Waste Battery Acid used for Reaction Analysis}

About 100 grams of the pulverised clam shells were used for the reaction against five labelled samples A, B, C, D and E of concentrations $4.5 \mathrm{M}$, $5 \mathrm{M}, 5.5 \mathrm{M}, 6 \mathrm{M}$, and $6.5 \mathrm{M}$ respectively.

The reaction for the formation of calcium sulphate is given by equation (4):

$$
\mathrm{CaO}{ }_{(s)}+2 \mathrm{H}^{+}{ }_{(a q)}+\mathrm{SO}_{4}{ }^{2-}{ }_{(a q)} \rightarrow \mathrm{CaSO}_{4(s)}+\mathrm{H}_{2} \mathrm{O}_{(l)}
$$

Fig. 8 shows the concentration and the corresponding volume of the acid used. Since the $\mathrm{CaO}: \mathrm{CaSO}_{4}$ molar ratio is 1 and $100 \mathrm{~g}$ of $\mathrm{CaO}$ was used as the control mass for the reaction, the maximum amount of $\mathrm{CaSO}_{4}$ that can be produced is $1.783 \mathrm{~mol}$. Concentration is inversely proportional to the volume, and thus the higher the concentration of the acid used for the reaction the lower the volume of acid required to react with $\mathrm{CaO}$. For sample A with concentration 4.5 M, 397 $\mathrm{ml}$ of WBA was used for the reaction; the volume of the acid decreases as the WBA concentration increases. Sample E of concentration 6.5 M required $274 \mathrm{ml}$ of the WBA for complete reaction. The gypsum produced is dependent on the availability of the WBA in excess. Sample E however, had limited acid for the reaction. The bed volume was very high due to a larger mass of PCS and small volume of WBA.

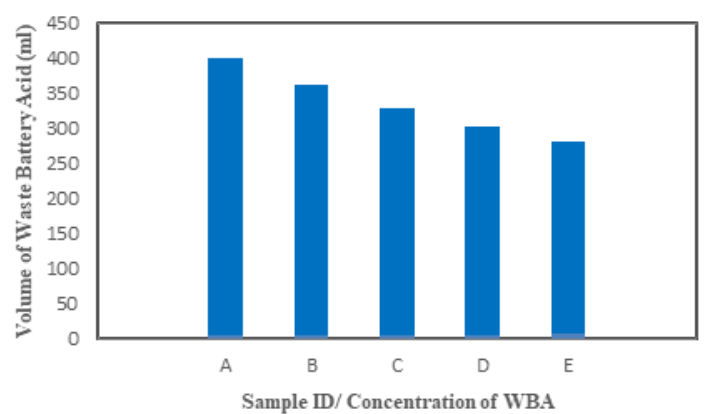

Fig. 8 Volume of Waste Battery Acid Used for the Reaction

\subsection{Reaction Time and Temperature Analysis}

Fig. 9 shows the maximum temperature difference that accompanies the $\mathrm{CaO}-\mathrm{H}_{2} \mathrm{SO}_{4}$ reaction and the time taken for the reaction to reach completion. The release of heat into the environment or surroundings results in the overall negative quantity for the heat of reaction $\left(\Delta \mathrm{H}_{\mathrm{rxn}}<0\right)$.

The reaction between the pulverised clam shell, which is predominantly calcium oxide $(\mathrm{CaO})$ and 
the waste battery acid (WBA) was very exothermic because the temperature of the system increased after the reaction. As shown in Fig. 9, higher acid concentrations gave shorter time for the system to attain their maximum temperature. The samples with low acid concentrations required longer reaction times. Samples D and E took 7 minutes for the reaction to attain its highest temperature difference of $69{ }^{\circ} \mathrm{C}$ and $71.2{ }^{\circ} \mathrm{C}$ respectively. The observed high temperatures were as a result of higher concentrations of the WBA used.

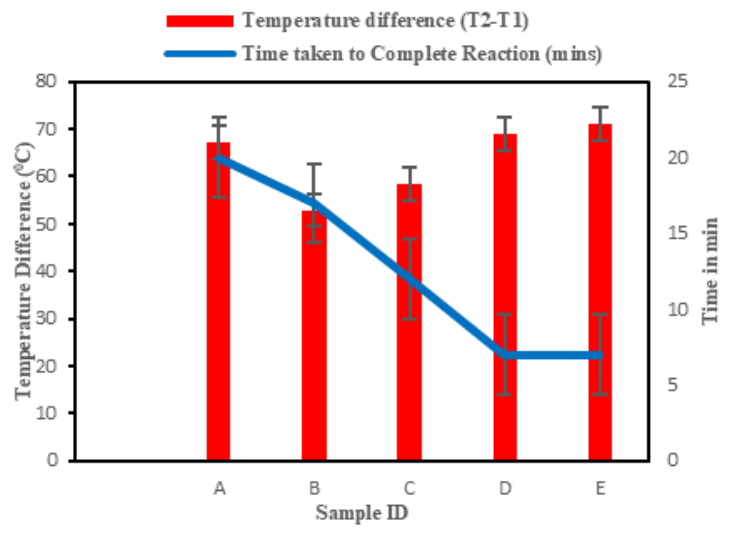

Fig. 9 Graph of Sample ID against Temperature and Time

\subsection{Analysis of the Dried Residue and the pH of Filtrate}

After the reaction has reached completion, the solution was filtered, and the solid residue dried; the $\mathrm{pH}$ of the filtrate was then determined. The initial $\mathrm{pH}$ of the Waste Battery Acid before the dilution to be used for the reaction was -1.04 which shows a hydrogen concentration of more than $1 \mathrm{M}$. From eqn. (1), the molar ratio involved in the reaction is $1: 1$. Accordingly, a mole of $\mathrm{CaO}$ will react with a mole of WBA.

The reaction of a metal oxide with an acid produces water and a metal salt; when calcium oxide reacts with sulphuric acid it produces bubbles of water vapour. After the reaction the $\mathrm{pH}$ of the various filtrates obtained were checked along with the masses of dried product obtained at various $\mathrm{pH}$. The highly concentrated $\mathrm{H}_{2} \mathrm{SO}_{4}$ that was used for the reaction was neutralised in the process. The masses of dried product obtained at various $\mathrm{pH}$ of the filtrate are shown in Fig 10. As shown in Fig. 10 , the $\mathrm{pH}$ of the filtrates was in the range $11.5-$ 12.5 .

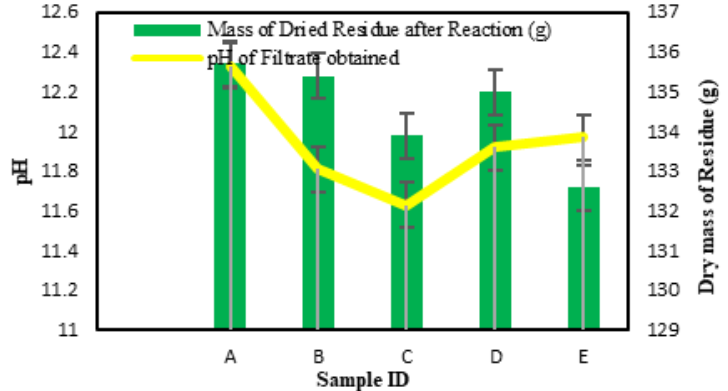

Fig. 10 Graph of Sample ID against the Dried Mass of Residue and pH of Filtrate

Experimentally, assuming $100 \%$ purity of the $\mathrm{CaO}$, $56 \mathrm{~g}$ of $\mathrm{CaO}$ must produce $136 \mathrm{~g}$ of $\mathrm{CaSO}_{4}$. The reaction of the pulverised clam shells with the waste battery acid was based on $100 \%$ purity of the reactants. The dry mass of the residue obtained after the reaction with the pulverised clam shells which was assumed to be $100 \% \mathrm{CaO}$ gave an average of 134.52 grams of $\mathrm{CaSO}_{4}$ at the end of the reaction. The masses of $\mathrm{CaSO}_{4}$ recorded for samples A, B and D were $135.7 \mathrm{~g}, 135.4 \mathrm{~g}$ and 135 $\mathrm{g}$, respectively. The observed slightly lower masses of the calcium sulphate obtained indicate that the pulverised clam shell does not contain $100 \% \mathrm{CaO}$ or the purity $\left(\% \mathrm{H}_{2} \mathrm{SO}_{4}\right)$ of WBA was lower than what was estimated. This is because the main components of calcined shells are $\mathrm{CaO}$ along with low levels of undesirable impurities, such as $\mathrm{Na}_{2} \mathrm{O}$, $\mathrm{SrO}, \mathrm{RuO}_{2}, \mathrm{Fe}_{2} \mathrm{O}_{3}$ and $\mathrm{CuO}$ (Nordin, et al., 2015). The mass of the gypsum produced at the end of the reaction is dependent highly on the excess WBA available, the concentration and also the extent of calcination of clam shells.

\subsection{XRD Analysis of the Original Clamshells and Dried Residue obtained after the Reaction}

The XRD patterns of the dried original clamshells are shown in Fig. 11 which displays sharp peaks of $\mathrm{CaCO}_{3}$. After the reaction, the residue that was oven dried at temperatures around $130{ }^{\circ} \mathrm{C}$ had almost the same colour as the pulverised clam shells. The XRD of the dried mass obtained after the clam shell-WBA reaction is shown in Fig. 12. Sharp peaks of all the three forms of gypsum, namely, anhydrite $\left(\mathrm{CaSO}_{4}\right)$, hemihydrate $\left(\mathrm{CaSO}_{4}\right.$. $\left.1 / 2 \mathrm{H}_{2} \mathrm{O}\right)$ and dihydrate $\left(\mathrm{CaSO}_{4} \cdot 2 \mathrm{H}_{2} \mathrm{O}\right)$ are present along with some $\mathrm{CaCO}_{3}$; this is a clear indication that the calcination of the clam shells is not fully complete and also that $\mathrm{SiO}_{2}$ is the basic impurity. From the XRD results in Fig. 12, the hemihydrate $\left(\mathrm{CaSO}_{4} \cdot 1 / 2 \mathrm{H}_{2} \mathrm{O}\right)$ was dominant followed by the anhydrite $\left(\mathrm{CaSO}_{4}\right)$ form of gypsum. 


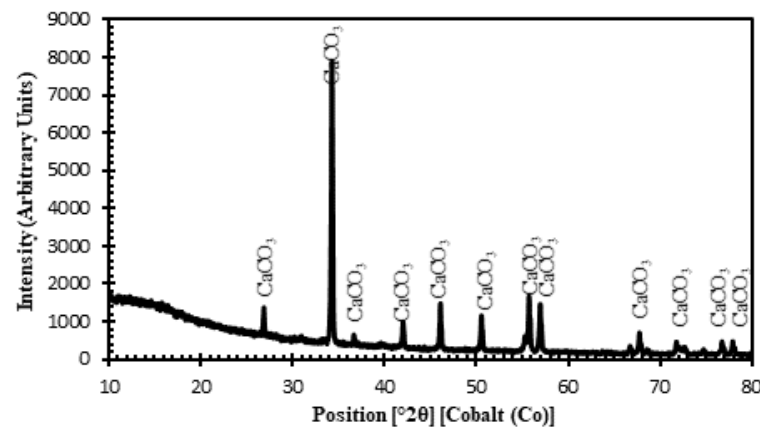

Fig 11 XRD Patterns of Pulverised Clamshells

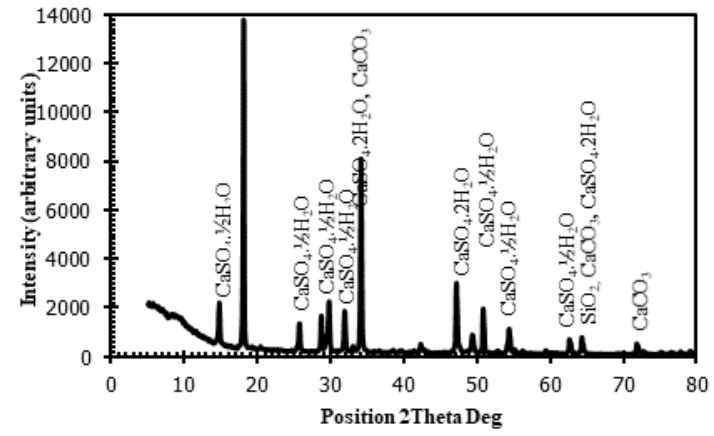

Fig. 12 XRD analysis of Dried Residue obtained from calcined clamshell-WBA interaction

\section{Conclusions}

This research work investigated the production of gypsum from clam shells and waste battery acid. It was concluded from this research that:

(i) Clamshells are rich sources of $\mathrm{CaCO}_{3}$ that can be calcined to produce $\mathrm{CaO}$ for subsequent production of gypsum.

(ii) Various forms of gypsum can be produced from calcined clamshell-WBA interaction.

(iii) All the three forms of gypsum (Anhydrite, Hemihydrate and the Dihydrate) were produced from the clamshell-WBA interaction.

(iv) Gypsum production is a potential route for recycling WBA.

\section{References}

Berg, S. V. D., (2009), "Recycling Used Lead Acid Battery", Rugby, Warwickshire: Practical Action, The Schumacher Centre for Technology and Development, $7 \mathrm{pp}$.

Bhanumathidas, N. K. (2004), "Dual Role of Gypsum: Set Retarder and Strength Accelerator", The Indian Concrete Journal, pp. 1- 4

Buasri, A., Chaiyut, N., Loryuenyong, V., Worawanitchaphong, P. and Trongyong, S. (2013), "Calcium Oxide Derived from Waste Shells of Mussel, Cockle, and Scallop as the
Heterogeneous Catalyst for Biodiesel Production", The Scientific World Journal, pp. 1-7

Gilchrist, J. D. (1989). Extraction Metallurgy, Pergamon Press, $3^{\text {rd }}$ ed., 431 pp.

Ni'mah, L., Manurung, F. B. and Pramita, E. (2018), "Lightweight Concrete Production by Gypsum from Waste Materials of Clamshell and Eggshell", J. Appl. Environ. Biol. Sci., Vol. 8, No. 1, pp. 125-133.

Ni'mah, L., Sutomo, E. W. and Simbolon, R. J. (2016), "Manufacture of Gypsum Board from Eggshell Waste Material", ARPN Journal of Engineering and Applied Sciences, Vol. 11, No. 16, pp. 9933-9940.

Nordin, N., Hamzah, Z., Hashim, O., Kasim, F. H. and Abdullah, R. (2015), "Effect of Temperature in Calcination Process of Seashells", Malaysian Journal of Analytical Sciences, Vol. 19, No. 1, pp. 65 - 70.

Olson, D. W. (2001), "Gypsum. U.S Geological Survey Minerals YearBook", pp. 35.1-35.5

Thorman, F. M., (1973), The Development of Gypsum Calcining. Society of Mining Engineers of AIME, pp. 1-10.

Treptow, R. S., (2002), "The Lead-Acid Battery: Its Voltage in Theory and in Practice". Journal of Chemical Education, 79(3), pp. 1- 5.

Warren, J. K., (2006), "Evaporites: Sediments, Resources and Hydrocarbons", BerlinHeidelberg: Springer, 1036.

\section{Author}

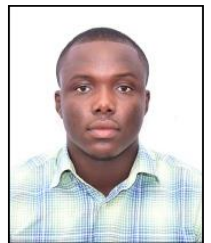

H. D. Gohoho is a National Service Personnel at Ghana Standards Authority, (Testing Directorate, Material Science Department, Petroleum Hall Marking and Assay Laboratory) Accra. He holds BSc degree in Minerals Engineering at University of Mines and Technology, Tarkwa, Ghana. His current research interest is in the recycling and refining of waste automotive engine oil and the production of gypsum from calcined clamshells and acids from spent lead accumulator batteries.

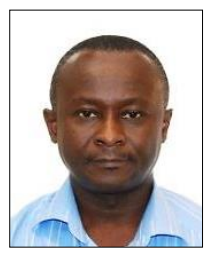

J. R. Dankwah is an Associate Professor at the Minerals Engineering Department, the University of Mines and Technology, UMaT-Tarkwa. He obtained his PhD from the School of Materials Science and Engineering, UNSW-Australia, MSc (Process Metallurgy) from the Norwegian University of Science and Technology and BSc (Metallurgical Engineering) from the Kwame Nkrumah University of Science and Technology, Kumasi, Ghana. His current research areas include iron and steelmaking, hightemperature metallurgical processes, utilisation of waste polymers in metal extraction processes and recycling agricultural waste into building blocks materials for affordable housing for the rural folks. He is a Fellow of the West African Institute of Mining, Metallurgy and Petroleum (WAIMM). 